\title{
Conference of the Association of Special Libraries and Information Bureaux
}

\section{$\mathrm{T}$} HE ninth annual Conference of the Association of Special Libraries and Information Bureaux, which was held at Somerville College, Oxford, on Sept. 23-26, opened and closed on a note echoed from the British Association meetings at York. In an opening address to the Conference on Sept. 23, on "Science and the Humanities", Prof. J. L. Myres directed attention to three characteristics of our own age, in the abundance of information and of working tools or instruments as well as of those who use them, linked up with increasing opportunities of use and the growing complexities of organisation directed to make both more accessible, and suggested that the depression which accompanies this superabun. dance of means is possibly no temporary depression. The leisure state may well be upon us and it is difficult to predict what the new order will be. All that can be said is that the situation must be met with new ideas and new projects, and Prof. Miles Walker's address at the British Association meeting was essentially a challenge to the present order and to the general outlook. With this the Association of Special Libraries and Information Bureaux is concerned in the provision of information relating both to accurate knowledge of the world and to the training necessary to make people competent to live. Sir Alfred Ewing's presidential address at the York meeting of the British Association likewise issued a challenge to modern politics, economics and systems of education and raised the whole question of the relative value of science and the humanities both in society and in the preparation of people for its privileges.

Prof. Myres pointed out that while the scientific method makes its chief contribution to human welfare in the assistance it gives in the observation and interpretation of experience, scientific achievement is at once impeded by the absence of moral qualities and æsthetic or artistic taste, and the humanities or human sciences such as human biology, psychology, statistical economics, make an equally important contribution in training human qualities, and the activities of the individual. The development of self-consciousness and self-control is an important aspect in social relations, and full use of information presumes the discernment of individuality in ourselves as in others. Accordingly moral, political, economic and social methods have a geographical or distributional aspect as well as a historical aspect. This, together with the distributional aspects of the systematic sciences, which only become directly applied to life when local or temporal conditions are involved, cuts right across the traditional view of the humanities and even raises doubts as to whether any real distinction is possible between the human and the pure sciences. Prof. Myres suggested that the teaching of a systernatic science should be humanised by paying more attention to its historical growth and regional application, and also that the teaching of the humanities might be clarified and intensified by a firmer distinction between their systematic aspect and those historical and regional reconstructions which alone can set the civilisations of the present in an intelligible perspective.

The same vigorous and refreshing outlook characterised the closing address to the Conference, in which, pointing out that the present depression is sapping moral as well as material resources, Mr. F. W. Pethick-Lawrence emphasised the importance of rational thinking on the situation and of discarding the old method of trial and error. Financial muddling is directly responsible for the crisis, and the way out of our difficulties lies in the intelligent use of accurate information, in treating finance not as an end in itself but as the handmaid of politics.

Comparing the present with previous Conferences, it is evident that the industrial representation is gaining strength and that despite its financial difficulties, the Association is steadily proving its worth and demonstrating the value of the co-operation which it has already established between special libraries and information bureaux. It is clear from discussions like that opened by Dr. S. C. Bradford on "Systematic Subject Indexes to Periodical Volumes" that there is still plenty of room for further co. operation. The intensely individualistic point of view of some special librarians or heads of informa. tion bureaux which was evidenced in this discussion probably deserves some of the strictures recently uttered against the expert and the specialist, and has sometimes led them to overlook practicul advantages in the decimal classification. On the other hand, those most interested in securing the adoption of the universal decimal classification have sometimes failed to realise the practical and even financial difficulties which at present beset the application of the classification in certain sections of industry. It is perhaps a little unfortunate that the Association devoted so much time at its conferences to a subject on which there is a strong cleavage of opinion, particularly as, with the growth of co-operation, the practical advan. tages of the decimal classification for many purposes may be more fully appreciated.

The discussion centring round the decimal classification was somewhat marred by the absence of an impartial chairman, but if any criticism is offered of the following discussion on the establishment and operation of an information service, it is that the joint paper circulated in advance to the Conference was treated at such length by the four joint authors that little time was left for discussion. This was evidently felt by the meeting, for a resolution was passed and adopted at the final session of the Conference, asking for a similar discussion on particular aspects of information services, especially in regard to co-operation, to be arranged at future conferences.

The discussion was opened by Mr. A. F. Ridley, of the British Non-Ferrous Metals Research Association, who stressed the advantages of an efficient information service in handling a far greater body of knowledge than could possibly be handled haphazard by individuals. Such a service, while not relieving individual members of the organisation from the duty of reading and digesting all information of importance to their work, assists them by selecting for them to read the information bearing on their special work. This work is educative as well as informative, inducing members of the organisation to make better use of the facilities offered. Special emphasis was placed on the selection of staff, as although much of the work is routine, it must never be allowed to become too much so. A very real part of the business of an information service is to safeguard the organisation for which it works from

No. 3285, VoL. 130] 
becoming hidebound with tradition. Initiative is of high importance, and the shortness of the timelag between publication of information and its being brought to the notice of the individual needing it is largely a matter of adequate library, technical and clerical staff.

Miss E. W. Parker, of the Mond Nickel Co. Ltd., stressed the value of external literature surveys conducted outside the library as a means of supplement. ing information received in the library. Much valuable advance information can be obtained by co-operation and by contact with technical and scientific personnel all over the world. As regards bibliographical work, Miss Parker suggested that it is important to produce bibliographies in advance of tine demand, and stressed the importance of attention to detail in such matters as well as in dealing with inquiries. It is doubtful whether any inaccuracies in such work can be des. cribed as minor. Mr. E. J. Carter emphasised aspects of the information service maintained by the Royal Institute of British Architects, stressing particularly the importance of maintaining a full service of journals and books inside the library and the value of propaganda regarding "the services offered. $\mathrm{Mr}$. T. M. Herbert described the information service recently developed as part of the research organisation of the London Midland and Scottish Railway.

An animated discussion, opened by Mr. J. P. Lamb, chief librarian to the City of Sheffield, with a paper entitled "The Public Library as an Aid to Industry and Research" and by Mr. B. M. Headicar with a paper, "Research: Where the Library and Librarian come in", focused attention on the general neglect of the municipal library by industry. Mr. Lamb referred to the possibilities of co-operation between the public libraries and special libraries in regard to co-ordination of purchases of books and the pooling of periodicals and storage space. In the course of discussion, Mr. Lamb directed attention to the changed conditions under which the reference library now operates and the necessity for some elasticity in adapting its former rigid procedure regarding the loan and exchange of books. Where local conditions permit rapid and easy book exchange a very useful field of co-operation between industrial and municipal libraries exists and a promising tendency is that towards the development of a pool of technical and specialised works between the strictly reference library and the general library.

Prof. M. Greenwood delivered a delightful paper on the "History and Sources of Official Vital Statistics" in which a keen sense of humour enabled him to make an apparently uninteresting theme eloquent and to convey to others something of the fascination the subject has for the expert as well as of the difficulties and pitfalls which beset those attempting to compare vital statistics or to base conclusions on them.

One of the most important discussions, to which very little time was allotted, however, was that initiated by Mr. A. A. Eldridge's report on the A.S.L.I.B. inquiry into technical and scientific abstracting. This inquiry was conducted by a small committee of which Mr. A. A. Eldridge was chairman and was the direct outcome of the informal conference convened by Mr. H. T. Tizard last year at the Imperial College of Science and Technology. The report presented by Mr. A. A. Eldridge was purely preliminary and outlined the general trend of the replies received to the questionnnaire. Some fifty replies had been received covering nearly ali the important abstracting agencies in Great Britain, including research associations and imperial bureaux, the Department of Scientific and Industrial Research, the Royal Photographic Society, the Textile Institute, British Medical Journal, Bureau of Chemical Abstracts, Institution of Civil Engineers and various industrial firms like the British Aluminium Co. Ltd., J. Lyons and Co. Ltd., Imperial Chemical Industries Ltd., Metropolitan-Vickers Electrical Co., Ltd.

The report directs attention to the opportunity for co-operation in the purchase or examination of journals of secondary interest and distinguishes between overlap in preparation and unavoidable overlap in publication. The replies received in answer to the questions regarding the qualifications for abstractors and their selection should provide the Association with a valuable analysis of experience as a basis for useful suggestions in response to definite requests for help. Divergent opinions were expressed as to the value of authors' summaries where provided, and opinion was expressed in the discussion on the report that abstracts must be written from the point of view of the user for whom they are intended. This is particularly true of the industrial abstracting services, but such services are frequently run deliberately to supplement and not to replace the work of agencies like the Bureau of Chemical Abstracts and the view that abstracts are best contributed by specialists in a particular field finds little support in industry. The discussion suggested that full time abstractors who are generally familiar with the subject and its principal complexities are regarded as most satisfactory for the special libraries or information bureaux. Attention was also directed to the desirability of uniform practice in regard to the abbreviations used for journal references, etc., and the transliteration of names in non-Latin scripts, as well as to the difficulties in the way of co-operation presented by the introduction of abbreviations into the text of abstracts.

At the annual meeting, discussion on the report and on what members want of A.S.L.I.B., initiated by Mr. H. Robinson of the Textile Institute indicated a very lively appreciation of the valuable work which the Association is carrying out and the wide and useful field of co-operation open to it. Sir Charles Sherrington was elected president of the Association in succession to Mr. H. T. Tizard.

\section{A Census of Summer Thunderstorms}

$\mathrm{T}$ HE first annual report of the Thunderstorm Census Organisation, Langley Terrace, Huddersfield, deals statistically with the records obtained, largely with the aid of private observers, during the six summer months April-September of 1931. It is an amateur enterprise conducted by Mr. S. Morris Bower as a sequel to a similar investigation carried on during a long period by Mr. C. J. P. Cave into the occurrence of thunderstorms in winter. The British Rainfall Organization, which is now part of the organisation of the Meteorological Office, Air Ministry, no doubt began in much the same way to supply information about one meteorological element with a greater degree of detail than could possibly be done without the aid of voluntary observers. The demand for such detailed information about

No. 3285, Vol. 1307 